\title{
Introduction to A Guide to Islamic Asset Management
}

Many individuals and institutions save money for future spending. That is true regardless of spiritual identity. People of all faiths habitually save for their future.

In all developed and many developing economies the savings of individuals and institutions are largely channeled through one or another type of asset management entity. An individual can walk into a local bank or go online and purchase mutual funds. A university endowment or family foundation will have a Board of Trustees establishing an investment plan, and will hire professional asset managers to implement that plan. Pension funds and insurance companies employ investment professionals internally or on an outsourced basis to manage their assets. Almost all have investment goals that must be achieved through security selection and asset allocation, the core functions of asset management.

Asset management in more-developed areas of the world, and many developing ones, is a well-established business with hundreds of thousands, perhaps millions, of employees and tens of trillions of U.S. dollars equivalent in AUM. It is by and large a secular business. While socially responsible and ethical investing have become new, important trends in the last decade, they are generally not by themselves spiritual.

What is common among the largest piles of money in the world-whether these be pension funds, endowments, insurance companies, family offices or even the savings of families - is the existence of multi-asset investing. It is commonly known that none or almost none of these savings entities put all their eggs into one basket. Multi-asset investing is based on the well-known principles of diversification. Wealth is more often managed in portfolios consisting of multiple sub-portfolios, one for each generic asset class: Cash, Fixed Income, Equities and Alternative Investments. These commonly found asset categories don't differentiate by spiritual affiliation. Multi-asset investing is common among people of all faiths.

While nearly all investors deal with multi-asset portfolio investing, professional asset managers deal with decision constraints on a regular basis. A client can be an individual or institution and give instructions to invest in assets of type "A" but not in assets of type "B." Some investors - such as the Methodist 
Church, the California State Employee Retirement System, the Norwegian SWF or the Bill \& Melinda Gates Foundation - provide specific constraints on their asset managers, usually involving the avoidance of investments involved in controversial businesses such as weapons, petroleum or gambling, or others considered anti-social, non-humanitarian or somehow defined as unethical or not socially responsible. So, adding constraints to security selection is not new; rather it's been extant for decades.

Modern Islamic finance can be said to have begun in 1975 with the foundation of Dubai Islamic Bank, and continued in 1976 with Bahrain Islamic Bank. Both institutions, and since then dozens more, are primarily retail banks. Retail banking in the Islamic sense means the same as with conventional banks: deposit-taking institutions that serve individual customer needs such as payment systems (debit cards or checking accounts), short-term credits, credit cards, auto loans and the like.

After a period of maturity nearly all the retail Islamic banks established parallel corporate banking services to serve business and government customers. For these customers they established Islamic payment systems, inventory finance, equipment finance, letters of credit and guarantee for exporters and importers, and the usual list of services provided to companies and agencies. Islamic corporate banking turned out to be identical to conventional corporate banking in terms of service, reliability and cost.

In 1998-1999 the world's first Islamic investment banking appeared, with Arcapita and Gulf Finance House in Bahrain raising an estimated \$30 billion from investors through 2007, and issuing close to $\$ 3$ billion in sukuk (Islamic bonds) for their own balance sheets. The world's first global sukuk was issued in early 2001 by the Malaysian government and was soon followed by more from the Dubai, Bahrain, Saudi and Indonesian governments. Sophisticated legal counsel created sharia-compliant share purchase agreements, mortgage loan agreements and long-term asset financing contracts that became widely accepted by sharia scholars. By 2014 even the U.K., Hong Kong, South Africa and Luxembourg governments had issued sukuk, indicating that a highly legitimized form of Islamic investment banking had been achieved.

Sharia-compliant trading and brokerage banking was established in the Islamic finance space with the likes of Mubasher, a highly popular independent Saudi brokerage and clearing house for regional and some international shares and mutual funds, while throughout the 2000s banks in the Saudi and Gulf region set up numerous sharia-compliant brokerage units, often in separately capitalized investment divisions, all generally recognized as providing the same level of service and cost as their conventional counterparts.

In short, these four pillars of Islamic banking - retail, corporate, investment, and brokerage and trading-have rapidly advanced over the last 40 years to become legitimate financial service providers for their respective clientele, 
widely accepted as equal in nearly all senses to conventional financial service providers. The only difference in nearly all cases, of course, was the addition of sharia certification.

Absent in the evolution of Islamic finance, however, is the fifth pillar of banking: Islamic asset management. Compared to the other four areas of banking, Islamic asset management has barely moved. Total assets in the Islamic finance system worldwide at the end of 2017 was measured at $\$ 2.4$ trillion, ${ }^{1}$ being expected to grow to $\$ 3.2$ trillion by $2020,{ }^{2}$ yet assets in sharia-compliant mutual funds total only slightly above $\$ 60$ billion, or just under $3 \%$ of assets in Islamic finance. Compare that to the approximately equal amounts of assets in U.S. mutual funds and U.S. commercial banks (about $\$ 15$ trillion each, meaning mutual fund assets are approximately equal to $100 \%$ of banking assets) and the disparity between Islamic AUM and Islamic finance assets becomes more acute.

There may be multiple causes for the retarded development of Islamic asset management. Certainly the advances in the other four categories of Islamic banking were swift and widespread. From near-zero levels in 2000, sukuk outstanding worldwide has now reached almost $\$ 500$ billion, Islamic mortgages in the United States are said to exceed \$3 billion, while sharia-compliant assets in the Malaysian banking system are quickly approaching $30 \%$ of all assets.

We consider here Islamic asset management as a unique and separate function of Islamic finance. Perhaps the retarded development of Islamic asset management is due to the lack of adoption of conventional asset management methodologies. Perhaps too there are cultural or social issues involved. The purpose of this study, however, is to seek whether one can follow professional and regulatory best-practice to isolate a minimally sufficient investible universe of sharia-compliant investments, and then determine the outcome from using this universe in optimized, multi-asset portfolio constructions, all within the context of MPT. If the results indicate feasibility within the confines of theoretical and practical constraints, then perhaps subsequent research can determine how to implement Islamic asset management on a wider scale.

There are two distinct areas of original research that follow. The first area of research is finding and then organizing a set of data of sharia-compliant investible securities in all major asset categories. The subsequent dataset must be free of labeling errors and sufficiently reliable to support research in the second area, as well as any conclusions. The second area of research is using that set of data to create optimized multi-asset portfolios that can test the hypothesis: "A sharia-compliant optimized portfolio, constructed identically to conventional (non-Islamic) portfolios, will demonstrate superior return and risk characteristics compared to its conventional peers." To begin the first area of research one must determine the size and nature of the sharia-compliant 
investible universe and then examine it according to professional standards common in the global asset management industry.

Here we seek to determine whether like-for-like multi-asset portfolio constructions-Islamic and conventional-may exhibit different performance characteristics. A null hypothesis may be: "There is no difference in risk and return between Islamic and conventional multi-asset optimized portfolios." Another null hypothesis may be: "Because of additional constrained security selection, an Islamic multi-asset portfolio will underperform an equivalent conventional multi-asset portfolio." While this study does not address the potential null hypotheses, one can infer the validity of them from the results that follow.

Once a reliable dataset has been established, we can ask:

Research Question: What are the performance (and risk) characteristics of multi-asset optimized portfolios comprising sharia-compliant securities as measured by contemporary risk and reward metrics, and how does this performance compare to conventional (non-Islamic) peer portfolios that are equally constructed?

The size and nature of the sharia-compliant investible universe and its utility for professional asset managers with "common man" clients are first addressed. We know conventional portfolio management is dependent entirely on reliable datasets for optimization and subsequent asset allocations to work, so establishing an investible universe across all asset categories that meets industry and regulatory standards is presumably the first priority in any envisioned subsequent Islamic asset management process. In fact, we can say that the Research Question cannot be addressed without first responding to the question of reliable data. So, we start with finding the data and insuring its utility for subsequent applications in portfolio construction and measurements.

The empirical analysis that follows will apply the resulting data on qualifying securities discovered in the Islamic investible universe to optimized multi-asset portfolio constructions in strategy styles seen as typical in conventional asset management. The results will be tallied and compared to conventional peers in identical investment strategies.

The first part of this work will focus on finding, labeling, measuring and analyzing the sharia-compliant investible universe, while the second part examines the process of establishing optimized, multi-asset portfolios and measuring their performance against conventional peers.

It is hoped that the results of this effort will stimulate others to expand on research relating to Islamic asset management. The dearth of studies on multi-asset, sharia-compliant portfolio investing reflects the essentially new 
nature of Islamic finance generally, and even more so the absence of Islamic asset management by any meaningful measure.

\section{NOTES}

1. Thomson Reuters Islamic Finance Development Report 2018, see https:// repository.salaamgateway.com/images/iep/galleries/documents/2018112512474 4259232831.pdf.

2. S\&P forecast, 19 October 2015, see http://english.mubasher.info/news/2829566/ Islamic-finance-to-reach-3trln-next-decade-S-P-s. 